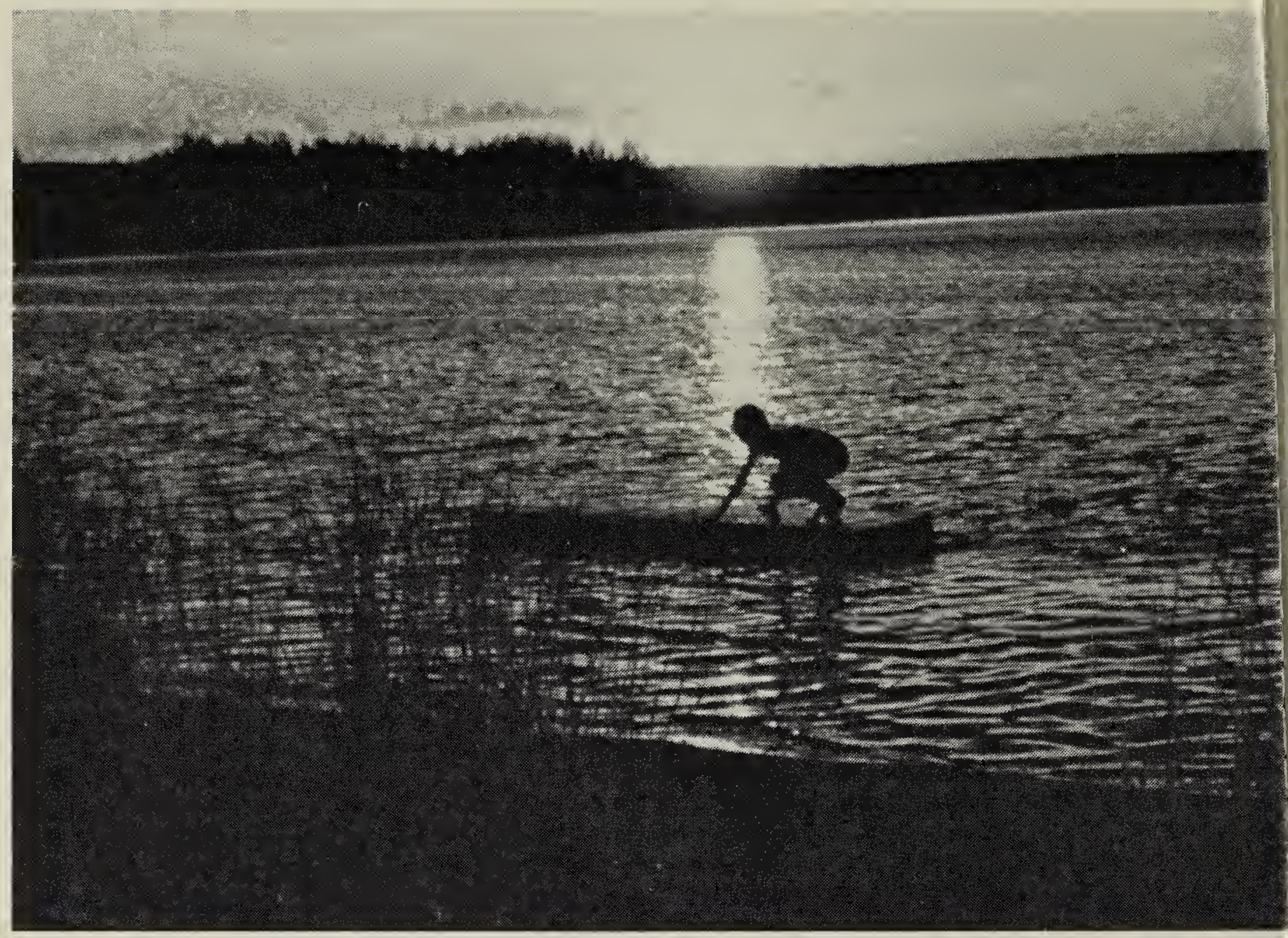

\title{
IMPACT OF OIL SANDS PLANT
}

J. DAVID HENRY, Saskatchewan Chapter of the National and Provincial Parks Association of Canada, P.O. Box 1624, Prince Albert, Saskatchewan, S6V 5 T2.

What impact will the development of the oil sands along the Alberta border have on Saskatchewan? This is a question that needs serious and immediate consideration now that Imperial Oil Ltd. has made an application to build a 4.7 billion dollar plant near Cold Lake, approximately 25 miles west of Meadow Lake Provincial Park. The Company proposes to recover deeply buried bitumen (tar) by injecting pressurized steam into deep wells. The bitumen would then be upgraded to a synthetic crude oil. The production capacity of the operation is estimated to be 141,000 barrels of synthetic crude oil per day.

Imperial Oil has also made application to mine 2.5 million tons of coal per year at Judy Creek, Alberta, to generate steam and electricity for the bitumen extraction and upgrading operations.

Imperial Oil provided a preliminary environmental and socio-economic impact assessment to the Alberta Engergy Resources Conservation Board (AERCB) in May 1978, and public hearings on the proposal were held at Grand Centre, Alberta, from 4 December 1978 until 18 January 1979. The Saskatchewan Chapter of 
he National and Provincial Parks Association was one of several bitizen groups that presented briefs th these public hearings. The chapter expressed concern about the project pecause of its possible adverse efects on Saskatchewan lands.

\section{Possible Impact on Saskatchewan}

The project, if approved, will remove 580,000 barrels of fresh water per day from Cold Lake. The impact of this water removal on the waterfowl and fisheries habitat along Cold River and Waterhen River in Meadow Lake Provincial Park may be considerable.

After being polluted (both chemically and thermally) this water will have to be disposed of. Imperial Oil is apparently planning both deep well disposal (which could affect groundwater quality) and discharge of effluents into the Beaver River, a tributary of the Churchill River.

The bitumen to be recovered is high in sulphur content. As a result, hydrogen sulphide and sulphur dioxide, produced during the upgrading process, may become serious air pollutants in the neighbouring areas of Saskatchewan.

\section{Analysis and Mitigative Measures}

Basically Imperial Oil proposes to use 2.5 million short tons of coal and 350 megawatts of electricity on an annual basis in order to produce 141,000 barrels per day of synthetic crude oil. The Chapter views this proposal as an inefficient chain of interfuel conversions. Furthermore, we view this project as a capital and resource intense proposal that is not based on conversion of our energy requirements to renewable resources; nor does the Imperial Oil application consider the end-use ef- ficiencies or energy quality of the resources consumed in its production process.

We expressed concern that the Cold Lake project was being considered in isolation, rather than identifying environmental standards appropriate for the region as a whole. A procedure should have been initiated to establish development guidelines for the total area encompassed by the Cold Lake/Lloydminster heavy oil deposit. There are at least five other oil companies interested in similar types of development; if approved, each of these developments will have similar impact upon the region. Furthermore, strict water regulatory and air emission standards are needed since some of these projects will be adjacent to prime recreational lands such as Meadow Lake Provincial Park. This park has rich terrestrial and aquatic wildlife resources which deserve the strictest of environmental control regulations.

The Chapter is critical of the plan to use coal from Judy Creek, Alberta, as a balancing fuel in the Cold Lake project. The Judy Creek coal mines would be adjacent to an area of the Swan Hills that has been recommended for a wilderness recreation area and contains an important IBP ecological site. We note that the Imperial Oil application states that desulphurized bitumen from the upgrading process could be used as an alternate balancing fuel with the result that the production process would operate at $89 \%$ efficiency $(125,000$ barrels of synthetic crude oil per day instead of 141,000 barrels). The Chapter recommended that this alternate balancing fuel be thoroughly investigated regarding cost-benefit and environmental impact and incorporated into the project if at all possible.

With regard to air quality, the main 


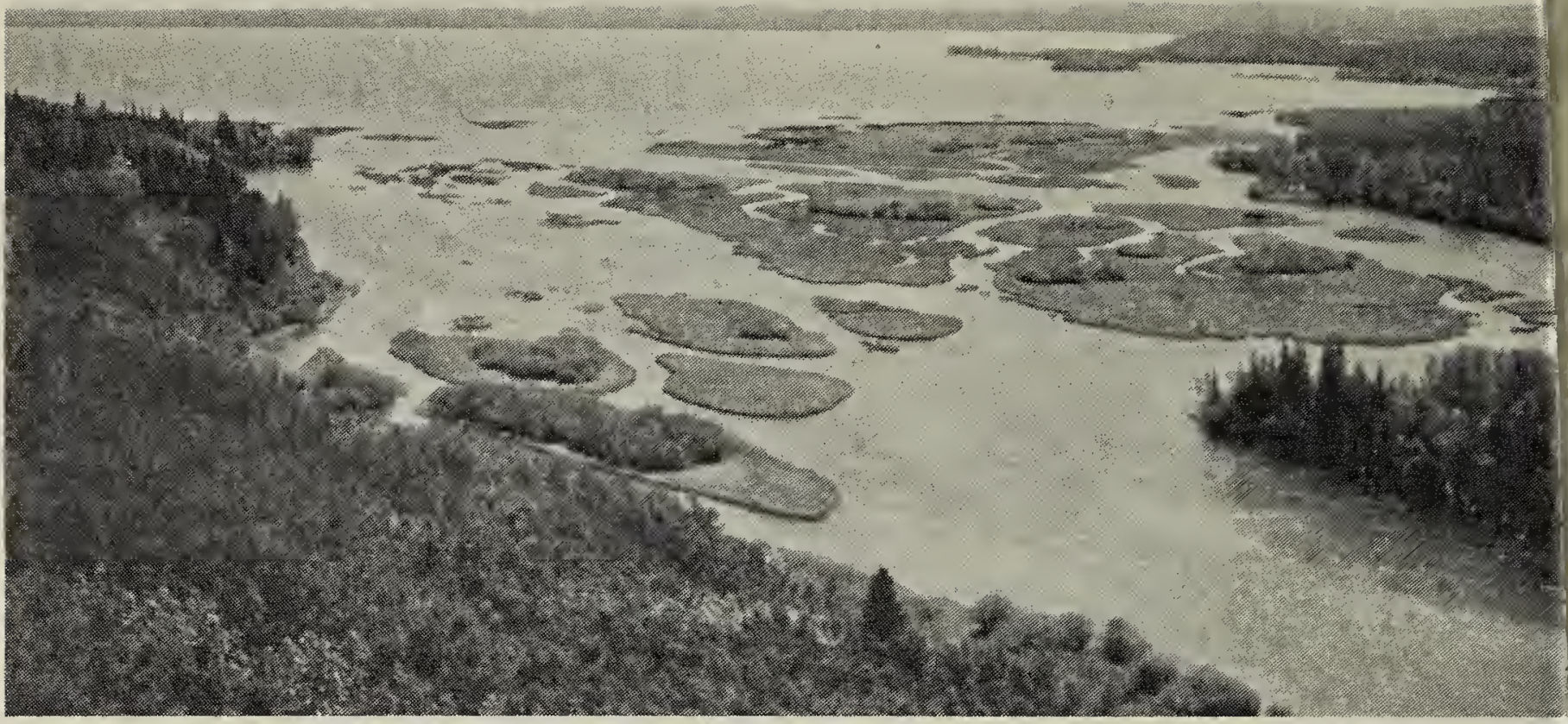

Cold River entering Pierce Lake, Meadow Lake Provincial Park

P. Albertsol

concern lies largely with the cumulative pollution from existing and future projects in the region. The Chapter is particularly concerned about the possible effects of airborne sulphur emissions on adjacent lakes in Saskatchewan since these lakes have been shown to be among the most productive commercial and sport fishing lakes within the province. The Chapter recommended that Environment Canada take a leading role in estimating the possible impact of sulphur emissions from the several heavy oil plants that may be located in this area. The object of this research should be to determine the need for emission standards on an interprovincial regional basis.

Another concern is that seepage from project-related tailing ponds and lagoons may enter the groundwater regime. Although Imperial Oil has outlined the measures that would be taken to prevent or minimize seepage, it has not described a monitoring system for early detection of seepage should it occur, nor has it indicated how containment would be effected.

The AERCB public hearings on the
Cold Lake project were poorly adver tised in Saskatchewan. Furthermore Saskatchewan's interests are no represented on the AERCB. Yet the water and air effluents of the Cold Lake project may have considerable impact on Saskatchewan lands. Since this is the case, the Chapter recommended that public hearings on the project be held in Saskatchewan so that our province's interests and concerns can more adequately be reviewed. The Chapter also recommended that a representative from the Saskatchewan Department of the Environment be allowed to serve as an adjunct member of the $A E R C B$ during the final decision making process concerning this project.

The Chapter encourages individual citizens who are concerned about the possible impact of the Cold Lake project on Saskatchewan to express their concern to provincial government officials. It is particularly important that proper environmental approaches and standards be adopted for this project since it is likely to be the first of a series of developments proposed for the heavy oil belt that straddles the provincial, boundary. 